\title{
Masalah Pendidikan dan \\ Pemecahan Masalah Pendidikan
}

\author{
AFRINALDI
}

afrinaldib@gmail.com

\begin{abstract}
ABSTRAK
Permasalahan pendidikan merupakan persoalan penting yang sedang dihadapi oleh Negara kita saat ini. Permasalahan mengenai menurunnya kualitas pendidikan kita saat ini. Dikarenakan pada zaman sekarang tidak dipungkiri bahwa setiap tahunnya, setiap jenjang pendidikan terus mengalami kenaikan biaya pendidikan, akibatnya banyak diantara mereka yang putus sekolah, bahkan tidak sekolah karena terhalang masalah biaya pendidikan yang mahal. Oleh karena itulah melihat betapa pentingnya pendidikan serta berbagai banyaknya permasalahan yang dihadapi yang dapat menghambat keberlangsungan peningkatkan pendidikannya maka daripada uraian ini bertujuan untuk mengetahui bagaimana masalah pendidikan dan pemecahan masalah pendidikan di Negara kita ini.
\end{abstract}

Kata Kunci: pemecahan, masalah pendidikan.

\section{LATARBELAKANG}

Pendidikan merupakan suatu kebutuhan yang tidak bisa lepas dari kehidupan manusia. Pada zaman saat ini, pendidikan merupakan modal yang harus kita miliki dalam menghadapi tuntutan zaman. Maju mundurnya suatu bangsa dipengaruhi oleh faktor pendidikan. Jika pendidikan dalam suatu bangsa itu baik, maka akan dapat mencetak sumber daya manusia yang berkualitas baik dalam segi spiritual, intelegensi dan keterampilan. Selain itu, pendidikan merupakan proses yang penting dalam mencetak generasi bangsa selanjutnya.

Dalam Undang-Undang No. 20 Tahun 2003 tentang Sistem Pendidikan nasional dijelaskan Bahwa : Pendidikan adalah usaha sadar dan terencana untuk mewujudkan suasana belajar dan proses pembelajaran agar peserta didik secara aktif mengembangkan potensi dirinya untuk memiliki kekuatan sepiritual, keagamaan, pengendalian diri, kepribadian, kecerdasan, akhlak mulia, serta keterampilan yang diperlukan dirinya, masyarakat, bangsa, dan Negara.

Supervisi pendidikan adalah hal yang sangat penting dilakukan untuk meningkatkan mutu pendidikan. Mutu pendidikan sangat berkaitan erat dengan keprofesionalan guru dalam menghadapi permasalahan-permasalahan yang ada didunia pendidikan baik pada masa saat ini atau masa yang akan datang. Berdasarkan hal tersebut pendidikan merupakan faktor yang penting karena pendidikan salah satu penentu mutu SDM (Sumber Daya Manusia), dimana manusia dapat membina kepribadiannya dengan jalan mengembangkan potensi-potensi yang dimiliki sesuai dengan nilai-nilai yang ada di dalam masyarakat.

Berdasarkan uraian diatas, permasalahan dalam tulisan ini adalah (1) bagaimana masalah pendidikan yang terjadi? (2) bagaimana cara pemecahanan masalah pendidikan yang terjadi?. Tujuan tulisan ini untuk mengetahui cara yang dapat dilakukan untuk memecahkan masalah pendidikan? 


\section{PEMBAHASAN}

\section{Pemerataan Pendidikan}

Masalah pemerataan pendidikan adalah persoalan tentang bagaimana sistem pendidikan dapat menyediakan kesempatan yang seluas-luasnya bagi seluruh warga negara untuk mendapatkan pendidikan. Permasalahan ini timbul akibat masih banyaknya anak usia sekolah yang belum bisa ditampung dalam suatu lembaga pendidikan karena kurangnya fasilitas serta sarana yang disediakan, seperti gedung-gedung sekolah, tenaga pengajar, dan alat serta media belajar.

\section{Pemecahan Masalah Pemeratan Pendidikan}

Permasalahan pemerataan pendidikan ini dapat dipecahkan melalui beberapa cara. Cara-cara tersebut bisa secara langsung pada sarana pendidikan atau pada pelaku pendidikan. Pada sarana pendidikan, dapat dilakukan misalnya melalui cara pembangunan gedung sekolah baru di daerah-daerah pinggiran, perbaikan dan penggantian gedung sekolah yang tidak layak pakai serta pengadaan sistem double sift (bergantian pagi dan sore) untuk penggunaan gedung sekolah agar penggunaannya bisa merata.

\section{Masalah Mutu Pendidikan}

Masalah mutu pendidikan muncul ketika hasil pendidikan belum mencapai taraf seperi yang diharapkan. Rendahnya kualitas Sumber Daya Manusia pendidikan dan sistem pendidikan yang kita pakai dapat menjadi penyebab dari permasalahan di atas. Banyaknya pelajar Indonesia masih belajar dalam taraf menghafal saja. Dimana hanya berbekal hafalan tidak membuat tambahnya suatu kecerdasan maupun tambahnya kedewasaan seseorang. Di dalam belajar seharusnya disertai pemahaman terhadap suatu materi, sehingga pemahaman tersebut akan benar-benar menancap pada otak pelajar. Dan pada akhirnya, ketika ia harus terjun dalam masyarakat ia akan benar-benar bisa mengaplikasikan ilmu yang pernah ia pelajari tersebut.

\section{Pemecahan Masalah Mutu Pendidikan}

Sasaran pemecahan masalah mutu pendidikan adalah perbaikan kualitas komponen pendidikan dan mobilitas komponen-komponen tersebut. Upaya pemecahan permasalahan ini dapat ditempuh dengan cara: Mutu pendidikan dapat diketahui pada kualitas keluarannya.

Masyarakat tidak akan melihat proses bagaimana ia belajar. Yang dilihat hanyalah hasil akhir dari sekian lama ia menempuh pendidikan. Permasalahan yang banyak muncul sekarang adalah, apakah kualitas keluaran dari sistem pendidikan itu termasuk dalam pribadi yang benar-benar berkualitas sebagai manusia pembangunan. Dalam hal ini mampu membangun dirinya sendiri dan lingkungannya. Tetapi jelas tidak mudah mengukur mutu produk keluaran tersebut. Hal inilah yang membuat masyarakat menilai seseorang hanya pada hasil keluarannya saja, tanpa melihat proses pembelajaran dan proses mendapatkan keluaran tersebut.

\section{Masalah Efisiensi Pendidikan}

Masalah efisiensi pendidikan membahas bagaimana sistem pendidikan memanfaatkan sumber daya pendidikan yang ada untuk mencapai tujuan pendidikan. Hal ini tergantung bagaimana penggunan dari sumber daya tersebut. Akan dikatakan mempunyai efisiensi tinggi apabila penggunannya hemat dan tepat sasaran. Dan bila sebaliknya, maka efisiensinya rendah. Sumber daya yang dimaksud di sini antara lain adalah tenaga kependidikan dan sarana prasarana pendidikan.

\section{Pemecahan Masalah Efisiensi Pendidikan}


Permasalah efisiensi pendidikan lebih mengarah pada masalah kualitas, tentu saja ini dapat di pecahkan melalui pendekatan teknologi pendidikan.Hal tersebut dapat ditempuh melalui caracara pendekatan sistem, berorientasi pada peserta, dan pemanfaatan sumber belajar.

\section{Masalah Relevansi Pendidikan}

Masalah relevansi pendidikan mencakup sejauh mana sistem pendidikan mampu menghasilkan output dari proses pembelajaran yang sesuai dengan kebutuhan pembangunan. Output pendidikan diharapkan mampu mengisi semua sektor pembangunan yang beraneka ragam. Jika system pendidikan mampu menghasilkan output yang baik, potensial dan memenuhi kriteria yang dibutuhkan, maka relevansi pendidikan dianggap tinggi.

\section{Pemecahan Masalah Relevansi Pendidikan}

Permasalahan relevansi pendidikan dapat dipecahkan mealui cara-cara seperti:

- Perluasan dan pemerataan kesempatan memperoleh pendidikan

- Peningkatan kemampuan akademik, profesionalisme dan jaminan kesejahteraan tenaga kependidikan

- Melakukan pembaharuan sistem pendidikan

- Memberdayakan lembaga pendidikan

- Mengembangkan kualitas sumber daya manusia

KESIMPULAN

Pendidikan mempunyai hubungan yang erat dengan pembangunan. Pendidikan berperan untuk menyiapkan sumber daya manusia untuk pembangunan. Hal ini dikarenakan sasaran pendidikan adalah manusia yang merupakan pelaku dalam kegiatan pembangunan serta usaha pendidikan yang mempunyai orientasi ke depan dan harus dapat dijangkau oleh pemikiran manusia. Permasalahan yang timbul antara lain seperti masalah pemerataan pendidikan, masalah mutu pendidikan, masalah efisiensi pendidikan, dan masalah relevansi pendidikan. Untuk memecahkan permasalahan-permasalahn tersebut diperlukan rumusan tentang berbagai masalah yang bersifat pokok agar pemecahannya pun bisa tepat sasaran. Keempat permasalahan yang timbul tersebut dapat teratasi jika pendidikan mampu untuk:

- Menyediakan kesempatan pemerataan belajar

- Mencapai hasil pendidikan yang bermutu

- Terlaksana secara efisien

- Menghasilkan produk bermutu yang relevan

\section{REFERENSI}

\section{Undang-Undang RI No. 20 Th. 2003 Tentang Sistem Pendidikan Nasional}

Sari, M. (2014). Peningkatan pengelolaan sara dan prasarana pendidikn untuk meningkatkan kualitas pembelajaran di SMPN 5 Bukittinggi. Jyurnal Bahana Pendidikan, 636-648.

Hadijaya, Y. (2012). administrasi pendidikan. repository, 122. 